\title{
DYNAMIC CAPABILITIES AND COMPLEMENTARITY IN COMPLEX IT PROJECTS IN BRAZIL: DATAPREV'S EXPERIENCE
}

\author{
(iD) Valter Moreno ${ }^{1}$ Rodrigo Ferreira ${ }^{2}$ (D) Fernando Filardi ${ }^{3}$ \\ ${ }^{1}$ IBMEC-RJ / Universidade do Estado do Rio de Janeiro (UERJ). Rio de Janeiro, RJ - Brasil. valter.moreno@gmail.com \\ ${ }^{2}$ Empresa de Tecnologia e Informações da Previdência - Dataprev. Rio de Janeiro, RJ - Brasil.rodrigoferreira.adm@bol.com.br \\ ${ }^{3}$ IBMEC-RJ / Universidade Federal do Estado do Rio de Janeiro (UNIRIO). Rio de Janeiro, RJ - Brasil.fernando.filardi@ professores.ibmec.edu.br
}

\begin{abstract}
Objective of the study: Large IT projects are admittedly complex, expensive, and risky, and not always produce the desired business results. In this study, we draw on the Resource-Based View and the theory of dynamic capabilities to elucidate the dynamics that allow a company to extract value continuously from an investment in a large corporate system.

Methodology / approach: To accomplish this, we developed a case study on the implementation and post-implementation of an ERP system by Dataprev, a large Brazilian public company.

Originality / Relevance: Our study provides empirical evidence of the interplay among complementary IT and organizational resources and capabilities, and dynamic capabilities in a large ERP implementation project and subsequent events in a Brazilian public company. There is still a paucity of research on these three issues, especially in the context of emerging economies.

Main results: Our analysis of the primary and secondary qualitative data we collected showed that, over time, the company's dynamic capabilities worked to improve the complementarity of IT and organizational resources and capabilities. This allowed Dataprev to develop new synergistic resources and capabilities and thereby, increase its performance and competitiveness continuously.

Theoretical / methodological contributions: We describe these resources and capabilities, as well as the dynamics of their interactions, and discuss its theoretical and practical implications.
\end{abstract}

Keywords: Resource-Based View (RBV). Complementarity. Dynamic capabilities. Information technology investments. Enterprise Resource Planning (ERP).

\section{CAPACIDADES DINÂMICAS E COMPLEMENTARIDADE EM PROJETOS DE TI COMPLEXOS NO BRASIL: A EXPERIÊNCIA DA DATAPREV}

Resumo

Objetivo do estudo: Grandes projetos de TI são reconhecidamente complexos, caros e arriscados e nem sempre produzem os resultados de negócios desejados. Neste estudo, a Visão Baseada em Recursos e a teoria das capacidades dinâmicas são utilizadas para elucidar a dinâmica que permite a uma empresa extrair valor continuamente de um investimento em um grande sistema corporativo.

Metodologia / abordagem: Para tanto, desenvolveu-se um estudo de caso sobre a implantação e pós-implantação de um sistema ERP pela Dataprev, uma grande empresa pública brasileira.

Originalidade / Relevância: O estudo fornece evidências empíricas da interação entre recursos e capacidades organizacionais e de TI complementares, e capacidades dinâmicas em um grande projeto de implementação de ERP e em eventos subsequentes, em uma empresa pública brasileira. Ainda há escassez de pesquisas sobre essas três questões, especialmente no contexto das economias emergentes. Principais resultados: A análise dos dados qualitativos primários e secundários coletados mostrou que, ao longo do tempo, as capacidades dinâmicas da empresa contribuíram para melhorar a complementaridade dos recursos e capacidades organizacionais e de TI. Isso permitiu à Dataprev desenvolver novos recursos e capacidades sinérgicas e, assim, melhorar seu desempenho e competitividade continuamente.

Contribuições teórico-metodológicas: $\mathrm{O}$ estudo descreve esses recursos e capacidades, bem como a dinâmica das suas interações, e discute as suas implicações teóricas e práticas.

Palavras-chave: Visão Baseada em Recursos (VBR). Complementaridade. Capacidades dinâmicas. Investimentos em tecnologia da informação. Enterprise Resource Planning (ERP).

\section{CAPACIDADES DINÁMICAS Y COMPLEMENTARIDAD \\ EN PROYECTOS COMPLEJOS DE TI EN BRASIL: LA EXPERIENCIA DEL DATAPREV}

\section{Resumen}

Objetivo del estudio: Los grandes proyectos de TI se reconocen como complejos, costosos y riesgosos y no siempre producen los resultados comerciales deseados. En este estudio, la Vista Basada en Recursos y la teoría de las capacidades dinámicas se utilizan para dilucidar las dinámicas que permiten a una empresa extraer continuamente valor de una inversión en un gran sistema corporativo.

Metodología / enfoque: Para ello, se desarrolló un estudio de caso sobre la implementación y post implementación de un sistema ERP por parte de Dataprev, una gran empresa pública brasileña.

Originalidad / Relevancia: El estudio proporciona evidencia empírica de la interacción entre recursos y capacidades organizativos y de TI complementarios y capacidades dinámicas en un importante proyecto de implementación de ERP y en eventos posteriores, en una empresa pública brasileña. Todavía hay escasez de investigación sobre estos tres temas, especialmente en el contexto de las economías emergentes.

Resultados principales: El análisis de los datos cualitativos primarios y secundarios recopilados mostró que, con el tiempo, las capacidades dinámicas de la empresa contribuyeron a mejorar la complementariedad de los recursos y capacidades organizacionales y de TI. Esto permitió a Dataprev desarrollar nuevos recursos y capacidades sinérgicas y, así, mejorar continuamente su desempeño y competitividad.

Aportes teóricos y metodológicos: El estudio describe estos recursos y capacidades, así como la dinámica de sus interacciones, y discute sus implicaciones teóricas y prácticas.

Palabras clave: Vista Basada en Recursos (VBR). Complementariedad. Capacidades dinámicas. Inversiones en tecnología de la información. Planificación de Recursos Empresariales (ERP).

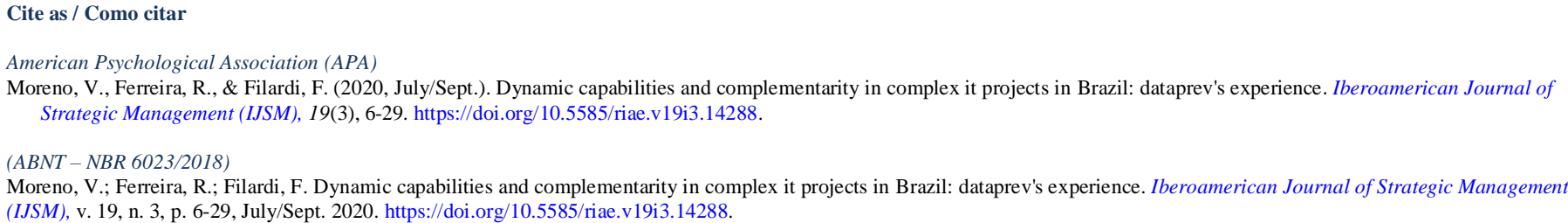




\section{Introduction}

Investments in Information Technology (IT) are often expected to increase organizational performance, generate business value, and foster the development of competitive advantage, as they allow companies to optimize business processes, develop fruitful relationships, and promote innovations in strategies and business models (Anderson, Banker \& Ravindran, 2006; Arvidsson, Holmström, \& Lyytinen, 2014; Melville, Kraemer, \& Gurbaxani, 2004; Schryen, 2013). Despite the steady growth of IT investments and a large number of studies on value generation and information technologies, many organizations still fail to obtain the expected benefits of their IT projects (Arvidsson et al., 2014; Karimi, Somers, \& Bhattacherjee, 2007). Even when such projects are successful, firms still face significant challenges after the implementation and stabilization of new complex information systems, which tend to hinder the continuous extraction of value from the investments that have been made (Chang \& Chou, 2011; Kouki, Poulin, \& Pellerin, 2010).

According to the Brazilian Association of Software Companies (ABES), Brazil's IT market was the largest in Latin America and the ninth-largest in the world, in 2018 (ABES, 2019). The country's software market alone was worth US\$ 10.7 billion in that same year and had been growing at rates significantly higher than the global average and the rates in developed countries. Nevertheless, IT investments do not guarantee the achievement of competitive advantage: it is how IT resources are effectively used by organizations that determines their ability to add business value (Mata, Fuerst \& Barney, 1995; Nevo \& Wade, 2010; Wade \& Hulland, 2004). Thus, companies that implement complex information systems must find ways and promote the internal adjustments necessary for the new technological resources to be used effectively over time and to generate sustained increases in efficiency and effectiveness.

Drawing on the Resource-Based View (RBV) (Barney, 2001) and the Theory of Dynamic Capabilities (Teece, 2007), in this study, we identify and evaluate resources and capabilities that seem essential for the continuous extraction of value from an IT investment. In particular, we shed light on the critical role played by complementary IT and organizational resources and capabilities in a firm's process of developing new resources and capabilities that potentially generate competitive advantage. To achieve this purpose, we studied the post-implementation phase of a Brazilian public company's large Enterprise Resource Planning (ERP) project. ERP projects are notoriously time-consuming, expensive, and complex; they involve a variety of resources and capabilities and are plagued by contingencies and breakdowns (e.g., Stanciu \& Tinca, 2013). In this way, they provide an ideal context for the investigation of the challenges and processes above.

The contribution of our study is threefold: (1) it provides empirical evidence of the interplay among complementary IT and organizational resources and capabilities, and dynamic capabilities; (2) it unveils the dynamics of continuous value-generation after the implementation of an ERP system; and (3) it discusses a large ERP implementation project and subsequent events in a Brazilian public 
company. There is still a paucity of research on these three issues, especially in the context of emerging economies.

\section{The resource-based view}

The Resource-Based View (RBV) establishes that companies achieve superior performance by developing skills and controlling resources that are scarce, valuable, and difficult to imitate and substitute for (Barney, 1991, 2001). Its origins are in the works of authors such as Penrose (1959), Selznick (1957), and Wernerfelt (1984). Selznick (1957), for example, was one of the first to characterize organizations as entities that acquire a unique character through the strategic choices they make as far as the development of resources is concerned. In this way, firms can be seen as "bundles of resources," which have an essential role in their growth (Penrose, 1959). These resources can be tangible or intangible assets, such as machinery, brands, technology expertise, individual skills, and efficient procedures (Wernerfelt, 1984).

Later, Barney (1991) argued that three factors contribute to making the set of resources a firm controls unique: (1) the specific sociohistorical conditions in which the firm has been embedded; (2) the degree of causal ambiguity in the links between controlled resources and competitive advantage; and (3) the extent to which these resources are very complex social phenomena. He builds on the assumption that resources are heterogeneously distributed across firms and that these differences are reasonably stable to argue that four traits determine the potential contribution of a resource to a firm's competitive advantage: value, rareness, imitability, and substitutability.

In the last two decades, authors have identified and described a variety of resources and capabilities (Chadwick \& Dabu, 2009; Huesch, 2013; Portugal Vasconcelos Ferreira, Reis, Ribeiro Serra, Costa \& Kramer, 2014; Wade \& Hulland, 2004). Wade and Hulland's (2004) study, for example, is of particular interest in this paper. As seen in Table 1, the authors identified eight essential IT resources and skills, which were classified into three categories: (1) Outside-In, which bring together resources and capabilities aimed to anticipate market requirements; (2) Inside-Out, which includes resources and capabilities used by the firm to meet the demands and market opportunities; and (3) Spanning, which involves resources and skills related to the integration of the company's IT department with the other business areas. 
Table 1 - IT Resources and Capabilities Categorization

\begin{tabular}{|l|l|}
\hline \multicolumn{1}{|c|}{$\begin{array}{c}\text { IT Resources and } \\
\text { Capabilities Type }\end{array}$} & \multicolumn{1}{c|}{ IT Resources and Capabilities } \\
\hline \multirow{3}{*}{ Outside-In } & External relationships management \\
\cline { 2 - 3 } Inside-Out & Market responsiveness \\
\hline & IT infrastructure management \\
\cline { 2 - 2 } & IT technical skills \\
\cline { 2 - 2 } & IT development \\
\cline { 2 - 2 } Spanning & Cost-effective IT operations management \\
\hline & Perform partnerships between IT and business areas \\
\cline { 2 - 2 } & IT planning and change management \\
\hline
\end{tabular}

Source: Adapted from Wade \& Hulland (2004: 113-115).

\section{Dynamic capabilities}

Criticism of RBV points out that the theory seems to assume that the resources and capabilities simply "exist" in an industry and that it focuses on the choice and selection of strategic resources at the expense of research of how such resources are developed and incorporated in organizations (Barney, 2001). The concept of dynamic capabilities (Augier \& Teece, 2009; Teece, Pisano, \& Shuen, 1997; Teece, 2007) emerges as a complement to RBV to mitigate this deficiency. Dynamic capabilities refer to the ability to reconfigure and modify existing resources and capabilities to promote changes in products, production processes, scale, or markets served by the firm (Winter, 2003).

Pavlou e El Sawi (2011) suggest that the dynamic capabilities are composed by four dimensions: (1) sensing, which refers to the organization's ability to detect, seek and interpret knowledge and opportunities in a turbulent market when receiving internal and external stimuli; (2) learning, which refers to the renewal of existing operational capabilities from the newly acquired knowledge; (3) integrating, that is, embedding new knowledge in the operational capabilities of the firm through the collective construction of meanings (sense-making); and (4) coordination, which refers to the assignment or implementation of tasks, resources, and activities into the reconfigured operational capabilities.

Dynamic capabilities are crucial in the face of environmental turbulence, where maintaining the alignment between a firm's resources and capabilities and the needs and business opportunities in the markets where the firm operates is critical to its competitiveness (Eisenhardt \& Martin, 2000). Therefore, dynamic capabilities tend to be essential for companies that are highly dependent on Information Technology, which evolves in an extremely dynamic and diverse competitive environment. 


\section{Complementarity and the generation of value with it}

In the last decades, Information Systems (IS) researchers have developed several models to explain how IT investments generate business value. However, the lack of consensus on the definition of value has hampered the accumulation of knowledge across empirical and conceptual studies. To address this issue, Schryen (2013) reviewed the extant literature and defined IS business value as "the impact of investments in particular IS assets on the multi-dimensional performance and capabilities of economic entities at various levels, complemented by the ultimate meaning of performance in the economic environment" (p. 141). Thus, although acknowledging the subjective nature of the construct, the author also stresses the impact on performance and capabilities as an essential criterion for assessing value. However, his comprehensive review also suggests that the Information Systems community has neglected or underestimated firms' internal capabilities when addressing IS business value.

Drawing on RBV, Melville et al. (2004) developed one of the most recent, prominent IS business value models (Schryen, 2013). As shown in Figure 1, its scope is comprehensive, encompassing from the internal resources, capabilities, and processes of the organization, to the characteristics of the macro-environment in which it operates (e.g., socioeconomic development level, market growth, local culture and the availability of technological and communications infrastructure). Although the authors address only process and organizational performance as outcomes of an IS investment, they do highlight the critical role played by different organizational and IT resources and capabilities in the generation of such results.

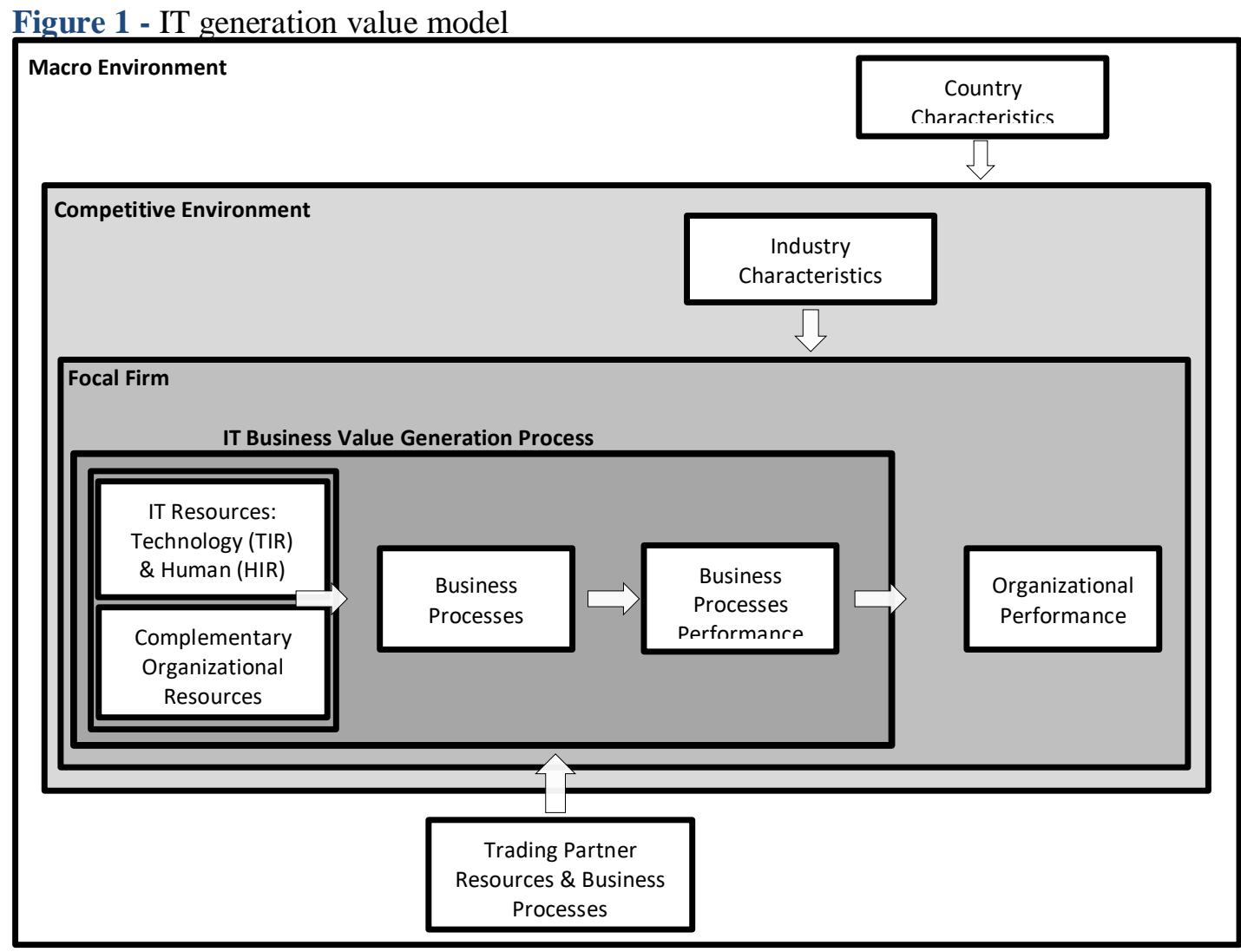

Source: Melville et al. (2004, p. 293). 
In their model, Melville et al. (2004) discuss two types of resources: IT resources and complementary organizational resources. IT resources are further divided into technological (TIR) and human (HIR) resources. It is important to note that, although the authors do not differentiate between resources and capabilities in their model, they do so when they develop their corresponding propositions. More importantly, Melville et al. highlight that the generation of business value can only occur when technological and human IT resources and capabilities and organizational resources and capabilities complement each other. Guarantying complementarity between resources and capabilities is, therefore, an essential requirement for the generation of business value from IT investments (Schryen, 2013). For Melville et al., much work remained in 2004, to uncover which resources are synergistic with which types of IT and in what contexts (p. 312). Almost ten years later, Schryen (2013) concluded that progress in this direction has been slow, as the particular relationships between IS assets and complementary capabilities, their roles in the value generation process, and the conditions under which competitive value is created remained unclear (p. 149).

Nevo and Wade's (2010) theoretical study is one of the few in the IS literature to tackle the mechanisms of complementarity. In their framework (Figure 2), they propose that complementary IT and organizational resources and capabilities can combine to generate synergies and sprout new resources and capabilities. The extent that the latter enable increased efficiency, the activation of new processes, improved services performance, and the identification of new opportunities or the removal of threats indicates their potential to generate value and competitive advantage. The generation of synergy is highly dependent on the level of compatibility between IT and organizational resources and capabilities, which, nevertheless, can be enhanced through integration efforts undertaken by the firm.

Figure 2 - Conceptual model of value generation with IT resources

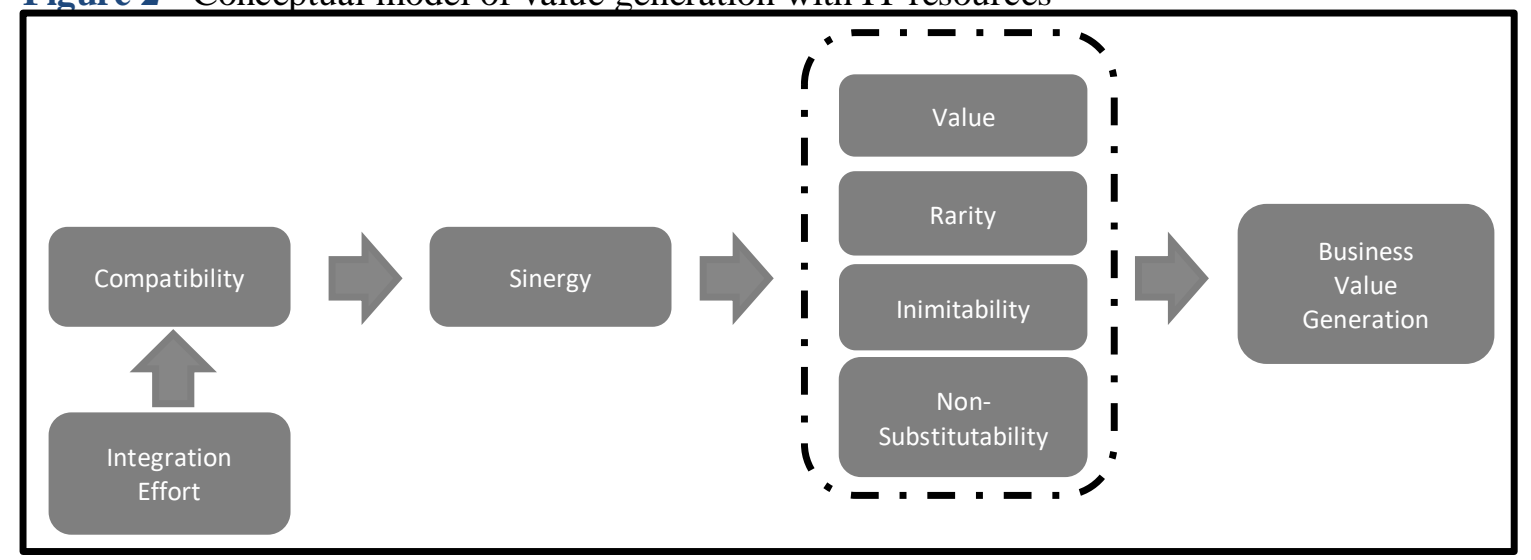

Source: Adapted from Nevo and Wade (2010, p. 171).

\section{Research method}

To achieve the previously stated objectives, we conducted an exploratory case study in Dataprev, a large Brazilian public company that provides IT services for the federal government. Our focus was on a major ERP project and its subsequent post-implementation phase. When the study was 
developed, one of the authors worked in the company and had access to participants and documents related to the project.

Several sources and types of data were included in the study. The primary data consisted of information collected in in-depth, semi-structured interviews conducted between October and November of 2014 with twenty-four managers and analysts of Dataprev's IT and business areas. The participants were purposefully selected so that we could get detailed information on the project and its aftermath from the perspectives of the various groups of stakeholders.

After obtaining the permission of the company, we contacted the potential participants. They were provided information on the objectives of the study and assured of the confidentiality of all information they provided. By the end of the data collection phase, we had been able to obtain the views of managers, project managers, IT professionals, and key users who had been directly involved in the project, as well as of employees that had been intensively using at least one of the ERP modules after the implementation of the system.

The secondary data included three types of internal documents, namely the contracts for the acquisition of the ERP system, Dataprev's IT Development Plan (PDTI), and several internal communications. Also, we were provided the results of the ERP user satisfaction survey that was conducted by Dataprev in December 2014.

The interview protocol consisted mostly of open-ended questions that covered participants' perceptions, experiences, and views on the events that took place during the project and after its conclusion, the challenges faced by stakeholders, and the positive and negative outcomes that have been generated. The interviewees included managers and employees who had taken part in the implementation project, as well as those who came to have contact with the system later and became heavy users. Nineteen participants worked in business areas of Dataprev, and five, in its IT area. Only six of them are female. At the time of the interview, four participants had been in the company for less than five years, and 20, for more than ten years.

The approximate number of words from the interviews is 39,000 and the average per respondent is 1,900 words. The acronyms of the respondents referenced in the paper followed a logic of the initials of their names combined with the initials of their areas of expertise in the company. The list of respondents was as follows:

Table 2 - Respondents profile

\begin{tabular}{|c|c|c|c|c|}
\hline Area & Characteristics & Number & Manager & Acronyms in the paper \\
\hline \multirow{2}{*}{ IT } & Male & 4 & \multirow{2}{*}{2} & \multirow{2}{*}{ STT / GST / OTI1 / ITU / ITA } \\
\hline & Female & 1 & & \\
\hline \multirow{2}{*}{ Business } & Male & 14 & \multirow{2}{*}{8} & \multirow{2}{*}{$\begin{array}{l}\mathrm{LOP} \text { / DAR / DCC1 / DRR / AER / DCP / CJR / } \\
\mathrm{ITI} 1 \text { / BTR / DGR / ITI3 / DIC / SGR / DAG / } \\
\mathrm{PGR} / \text { DCT / AAM / LXC / GVF }\end{array}$} \\
\hline & Female & 5 & & \\
\hline
\end{tabular}

Source: Research data. 
Interviews were recorded and later transcribed with the help of the Express Scribe software. The transcripts were submitted to the participants for the identification of inconsistencies. Three of them requested minor revisions, only. The edited transcripts were resubmitted to them and promptly approved. Later, whenever we felt it was necessary to clarify parts of the interviews during the data analysis process, we requested and obtained additional information from the participants by e-mail or phone.

Interview transcripts and all secondary data were analyzed in Atlas TI 7, a widely used qualitative data analysis software. We applied Friese's (2014) techniques to implement a qualitative content analysis strategy (Kohlbacher, 2006; Mayring, 2000) and generate our findings. For instance, after the development and application of our codes and categories, we identified the primary resources and capabilities involved in the business value generation process based on the respondents' voices with which related words and passages were mentioned by participants. This procedure was assumed to reflect the importance of those issues in the particular organizational context we investigated in our research.

To increase the validity of our findings and mitigate potential biases, we crosschecked participants' narratives against each other as well as against the documents we obtained in Dataprev. The documents were used in the triangulation process mainly to elucidate how the ERP solution was contracted, the company's expectations for the project, and the extent to which new resources and capabilities were developed. Any inconsistencies were taken back to participants for clarification. Later, after summarizing the results of the data analysis process, we requested interviewees to validate our overall interpretations. No significant issues were reported back to us. The triangulation and data quality and completeness checks contributed to increasing the validity of our conclusions.

\section{The ERP implementation project}

Dataprev, a state-owned company linked to the Brazilian Ministry of Social Security, is regarded as the leading IT service provider in the area of social security and welfare. According to its Strategic Planning 2010-2015, its mission was "to provide information and communication technology solutions for the implementation and improvement of the social policies of the Brazilian State."

When the possibility of implementing an ERP system was first raised, in 2005, Dataprev had been striving to become a more relevant player in the governmental sphere. Its efforts led it to receive several prestigious awards and increased its visibility in the IT sector in general. The acquisition of a corporate system that would help it achieve higher levels of operational efficiency and effectiveness was then seen as a natural step towards its strategic goals. In particular, the possibility of obtaining benefits such as increased scalability, rework elimination, replacement of legacy systems, and higher data integration, consistency, and resilience, was determinant to the decision to implement the ERP system. 
Figure 3 - Legacy Systems to Be Replaced

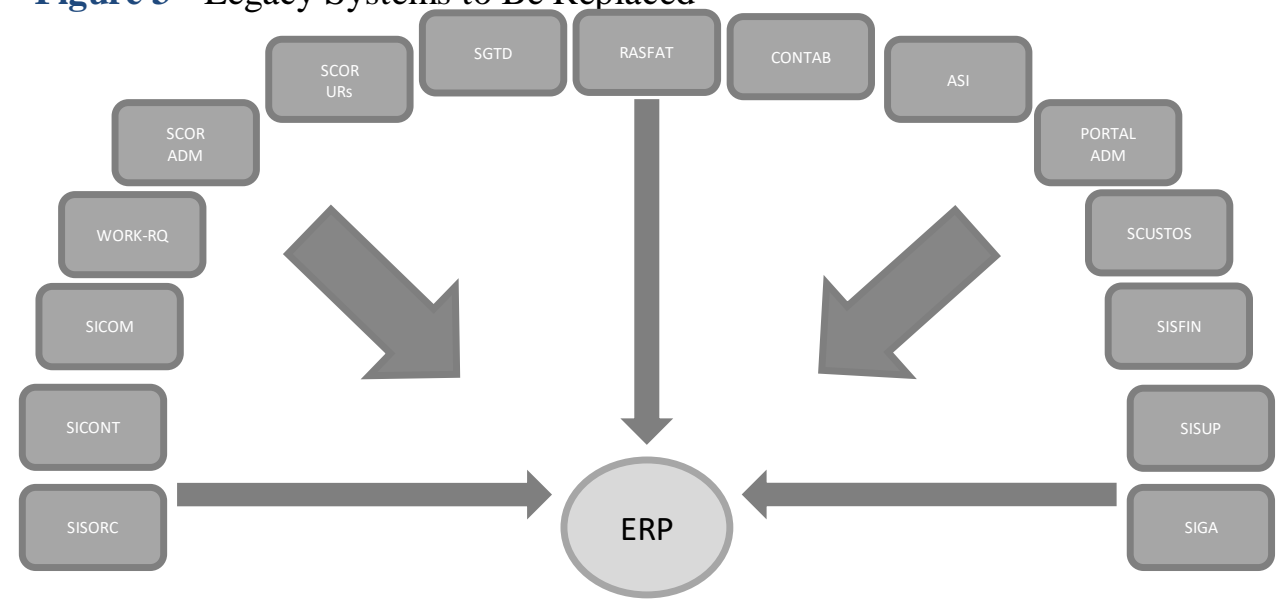

Source: Internal documents (adapted by the authors).

Figure 3 depicts the various legacy systems to be replaced by the new corporate system. They consisted mostly of unstandardized, unintegrated stand-alone applications that were spread throughout the various branches of Dataprev to support their work activities. Information exchange among these systems required considerable manual work, thereby reducing decision-making efficiency and efficacy, and jeopardizing the company's ability to achieve its objectives. As a manager of one of the business areas stated, "Information quality, lack of information integration, a number of systems that do not talk to each other, obsolete systems, rework, [and] too much manual labor were the reasons behind the decision to invest in ERP."

It was also expected that the adoption of a single database, which was part of the ERP project, would eliminate redundancies and inconsistencies that had been plaguing Dataprev's various fragmented databases. Sometimes, employees found themselves in embarrassing situations when realizing that different systems showed different values for the same variables. Data inconsistency created considerable barriers to the integration of business areas and processes in the company.

Dataprev's expectations for the ERP system were widely advertised internally and externally through several channels. One of them was "Cadernos de Debates," a publication of Dataprev's Information Technology and Communication Forum that was available on the company's website. The following excerpt is an example.

"As a result [of the project] we look for processes and responses improvement, redundancies and rework elimination, greater integration, among other benefits." (Caderno de Debates, no. 25).

In 2007, Dataprev's board approved a benchmarking and research effort to collect information and guide the decision on whether to purchase a third-party ERP system or to develop the system internally. Based on the results, it was decided to purchase an off-the-shelf product, especially as it would give Dataprev access to industry best practices, thereby helping it increase its efficiency and efficacy. 
As shown in Figure 4, the deadline set for the go-live of the system was January 2011. This goal was described in the company's strategic plan for the 2010 to 2016 period.

Several deliveries and events were scheduled and occurred before the go-live. For example, in addition to holding meetings and visits to public companies to know more about their experiences with ERP systems, Dataprev carried out two public consultations to get information on additional products offered in the market.

Figure 4 - ERP Implementation Timeline

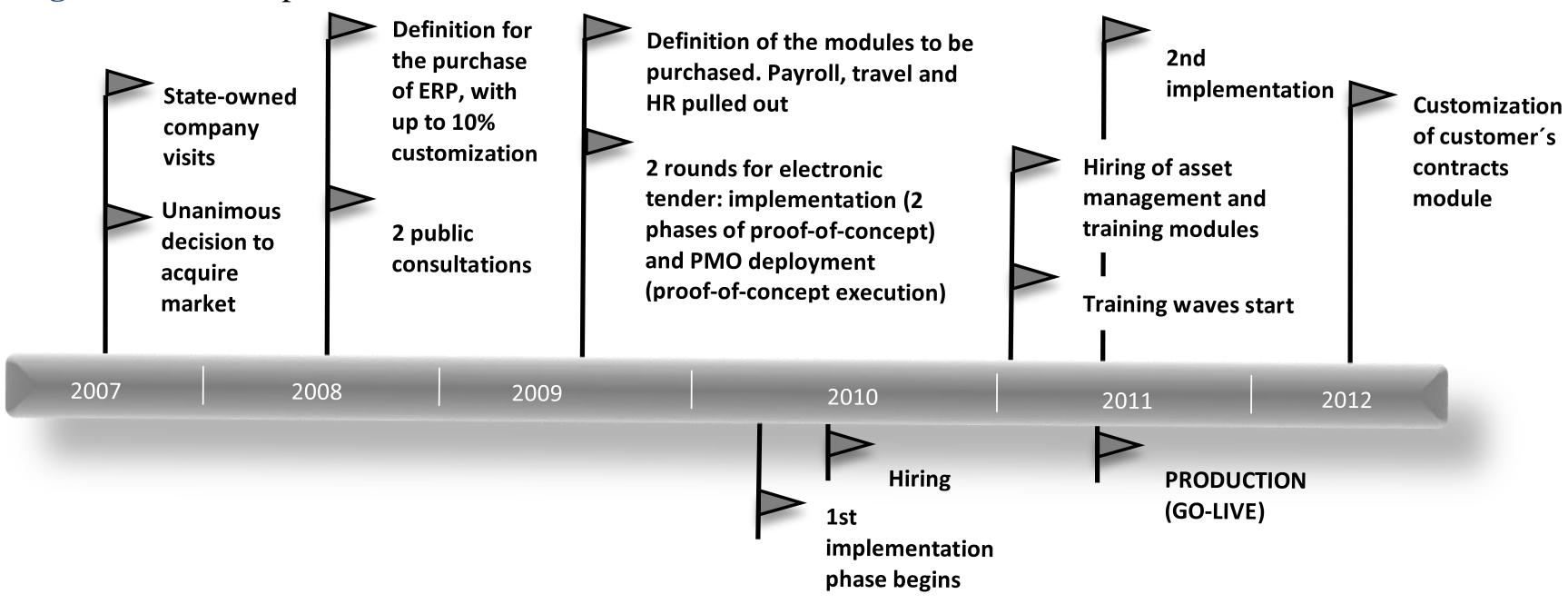

Source: Internal documents (adapted by the authors).

Once all information was collected and analyzed, it was decided to limit the customization of the system to $10 \%$. Based on the evaluation of the proof-of-concept developed by potential suppliers, Dataprev chose to purchase the system from Totvs, a Brazilian ERP company. Figure 5 shows the various modules that were to be implemented in the two phases of the project.

Figure 5 - ERP System Implementation Project Scope
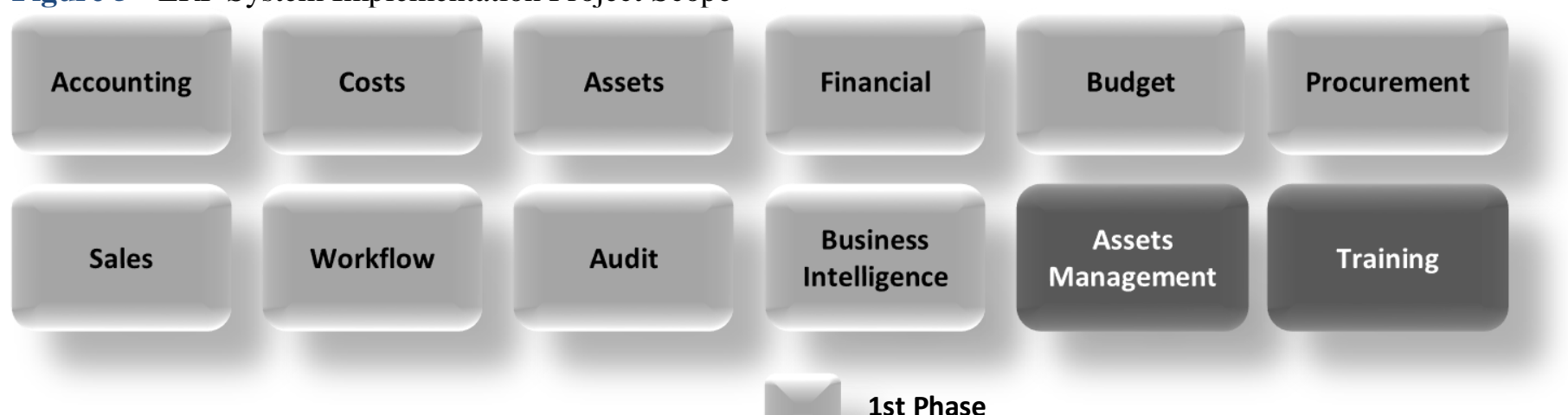

1st Phase

2nd Phase

Source: Cadernos de Debates, 25 (adapted by the authors). 
From the beginning, Dataprev recognized its lack of expertise in ERP implementation. Accordingly, it sought and hired an implementation contractor and a project management consulting firm to help it structure and facilitate the ERP system adoption process. In particular, change management was a significant concern for the implementation team. To mitigate users' resistance, Dataprev and the implementation contractor defined five major stages or "waves" in which change agents and users would be acquainted with the project and trained in the new system. The first wave consisted of identifying, recruiting, and training 40 change agents and multipliers that would compose the company's change management team. As this work progressed, the second wave was implemented, with the involvement of about 70 managers. The third wave included approximately 380 employees who performed activities of business processes that would be highly modified to accommodate the new system. Support teams and the remaining users were included in the fourth and fifth waves, respectively. It is important to highlight that the participants of the first wave received specific training on how to deal with resistance and promote a positive attitude toward the system. Trust, teamwork, and commitment were emphasized. Overall, employee participation was intense during the implementation process.

\section{Resources and capabilities in dataprev's project}

\subsection{IT resources and capabilities}

The eight IT resources and capabilities defined by Wade and Hulland (2004) were identified in the case, as described below.

- External relationships management: Dataprev was able to establish a strong relationship with the implementation contractor and the project management consulting firm, which was essential to the achievement of its goals. Dataprev's IT area itself sponsored several initiatives to foster the integration of the three companies, such as the XXV ICT Forum in Brasilia and the "Totvs Universe - T Day" 2011 event, with simultaneous transmission to more than 30 cities. The company's ability to establish and manage fruitful relationships with external partners was highlighted in this excerpt from Caderno de Debates: "The strong relationship between Dataprev, the implementer and the project consultancy was evidenced in the events: XXV ICT Forum [...]" (Caderno de Debates n. 25).

- Market responsiveness: The very decision to implement the ERP system, driven largely by Dataprev's desire to meet the demands of its clients, reveals the company's ability to identify needs and opportunities in the outside environment and act accordingly. The same applies to the inclusion of a BI module in the project to support the development and management of key performance indicators and improve Dataprev's relationship with suppliers and clients. 
Dataprev is investing heavily in BI, even to serve customers. And what is sought is to work on indicators to improve the management or our business - the relationship with suppliers and customers, purchasing processes, the evaluation of investment projects [...]" (Caderno de Debates n. 25)

In realizing the potential of this tool - a rather new technology at the time - Dataprev's IT department took advantage of a market opportunity to leverage business performance.

- IT infrastructure: The company equipped itself with the appropriate technological resources (hardware and software) for the project. The new IT platform consisted of 12 servers running Red Hat Enterprise Linux version 5 and Microsoft Windows Server 2003, Oracle Database 11g, and VMware ESX 5.5 virtualization software. The effort to make the necessary infrastructure available to the business is evident in the following excerpt.

Regarding capacity management, the team is always attentive to the meeting users' needs. Transactions increase, processes change, more and more users want access to the system. And as it is implemented, other demands are identified, and the number of accesses increase. (Caderno de Debates $n$. 25)

- IT technical skills: Dataprev's IT support department was able to constantly improve their knowledge of the ERP system and ERP technology in general, which evolved over time. In particular, they further developed and applied effectively their capacity and availability management skills within the context of the new ERP technology.

System monitoring is an obstacle not only for Dataprev, but for most organizations. The adoption of a registration management policy is essential because it is a very dynamic process, in which the lack of follow-up causes several problems with suppliers and products. (Caderno de Debates $n$. 25)

- IT development: Evidence of Dataprev's IT development capability included its thorough research and evaluation ERP solutions, the implementation of the selected ERP system, and the experimentation and adoption of new BI technologies to enhance business performance. In the following excerpt, the respondent points out IT's capacity to improve Dataprev's information systems to address business demands continuously.

Version 12 I've already seen working and it's a great improvement over what we have here [...] And as there is now in the [IT Department] ... it's a support area and we'll have 3, 4 years of systems. Now we will be together checking what the user wants, what the ERP is offering to us, and we will deal with that and will not miss a hole in the process. (OTI1)

- Cost-effective IT operations management: Dataprev was able to evaluate the costs and benefits related to the situation before and after the ERP implementation, and implement the solution and operational processes that would enable the system to function efficiently and effectively. For instance, after the go-live, it created a team to monitor the capacity and 
availability of the new IT assets and to adjust the processing power of the application and database servers and guarantee network availability whenever the workload of the ERP system increased.

It is common to buy a system and, when it is running smoothly with all its features, it ends up being left aside, unused, neglected on a daily basis. You don't pay cheap for a system. So, it is necessary to explore it as a whole and, if possible, more than it allows. (Caderno de Debates n. 25)

- Development of partnerships between IT and business areas: Before, during, and after the implementation of the ERP system, Dataprev's IT department sought the commitment of all related areas. After the go-live, the IT staff and the business areas maintained the frequent exchange of information, allowing technical staff to identify improvement needs and take corrective actions more promptly. Furthermore, a hot site was developed for the project to help employees obtain up-to-date information and become engaged in the project.

An interesting aspect was the dissemination of knowledge. For example, [...] we often received information from colleagues in other areas. In addition to the dissemination of the discovery of a little button, the user himself, with the use of the tool, [was able to] demands improvements..." (Caderno de Debates $n$. 25)

- IT planning and change management: A governance matrix was created and applied to enable the effective operation of the ERP system. On the one hand, it defined responsibilities for activities related to the day-to-day operation of the system, including receiving new demands, managing contract and service levels, requesting changes, developing improvements, and prospecting new technological solutions. On the other hand, it established an advisory committee and specified its composition and internal processes. The committee was composed of senior management representatives from all functional areas and was summoned whenever a significant change in the system was to take place. The committee's role was to assess and make recommendations to streamline the overall decision-making process.

\footnotetext{
Structuring is important because the reason for Dataprev's existence is the development of systems for its customers. And every time they have a demand, it is necessary to prioritize the service to them. The creation of an exclusive area to serve the middle area may perhaps bring the necessary balance. (Caderno de Debates n. 25)
}

\subsection{Organizational resources and capabilities}

The following organizational resources and capabilities were essential to the success of Dataprev's ERP project. 
- Organizational structure: During the implementation process, the company created new organizational structures to monitor system usage and provide adequate technical support, and to manage the new IT platform. The assembled teams engaged in specific training and development initiatives that helped them develop their skills and knowledge on the requirements, functionalities, programming language, and technologies related to the ERP system.

- Multidisciplinary workgroups: As mentioned before, a workgroup had been formally designated to research and comment on the acquisition or development of an ERP system. Later, Dataprev created a diverse project team and maintained the aforementioned advisory committee. Together, they were essential to increase engagement and commitment of the various stakeholders, streamline decision-making, and increase the effectiveness of the decisions made during the project and after the go-live.

In 2008, in possession of these five reports from the five heterogeneous working groups, the Executive Board decided in a specific meeting to set up a working group to start the bidding process up to the electronic auction for the acquisition of an ERP system for Dataprev". (Respondent ITU)

- Processes management: The implementation contractor hired by Dataprev helped the company analyze and redesign its processes. This capacity is usually critical in a corporate system implementation project and was vital to the achievement of the company's objectives. It continued to be essential to the successful operation of the system, as new business needs arose and required changes in processes and ERP modules. The 10\% restriction in the customization level made this capability even more critical, as most of Dataprev's operations had to be standardized to follow the best practices embedded in the ERP system.

"I participated actively in the implementation process. The participation had an important stage, which was the survey of the existing processes (as is) and the future process (to be)" (Respondent BTR).

- Change management: This capability was externally acquired from the implementation contractor and developed throughout the ERP project. It was essential to reduce resistance, expedite business process changes, and facilitate the implementation of new organizational structures, roles, and policies.

\footnotetext{
"The great gain of this implementation was the learning we had with the work of managing organizational change..." (Respondent OTI1)

"When we talk about organizational change management, the first pillar that we highlight is stakeholder involvement, who are the stakeholders? they are the mere sponsors, they are the managers, they are the guys who need to take that little flag of the project. We defined a strategy for involving these people [...] the management strategy of change that we built was very focused on this issue" (Respondent ITI1)
} 
- Communication: Widely used during the implementation of the ERP system, Dataprev's ability to communicate effectively with all involved players proved to be extremely important to obtain staff's commitment and mitigate threats and internal turmoil.

The transparency of the process proved to be fundamental to its success. In this respect, communication has a prominent role. For this reason, we continued to work on raising awareness and distributing internal communications and other guidelines, using the communication channels available at the company. (Caderno de Debates $n$. 25)

- Senior management commitment: Senior managers demonstrated their commitment throughout the implementation, ensuring the allocation of required resources, the delegation of appropriate authority and accountability, the development and application of a careful decision-making process aligned with the company's interests, and the engagement of the workforce.

\footnotetext{
"Another possibility is the creation of an advisory committee, with representatives from all boards. The group would take action whenever it was necessary to make a major change in the system, when new solutions or new demands arose ... The idea is to speed up the process...". (Caderno de Debates n. 25).
}

- Change readiness: Dataprev's readiness to change was evident in the study. Driven by the difficulties they had been facing until then, the possibilities the new ERP solution would bring, and managers' and change agents' active encouragement, people became excited about the project. Employees shared an optimistic view of the changes that would take place. This positive attitude was maintained after implementation, thereby assisting the achievement of corrective actions and improvements to the system.

It was crazy work, but on the positive side, it put everyone's commitment to wanting the thing to work, that the system really be implemented. (Respondent DIC)

- Partnerships with suppliers: Dataprev was able to strengthen relationships with the contracted suppliers, which were all imbued with the importance of achieving the project's objectives. This partnership not only allowed problems to be solved faster, but the implementation of improvement opportunities suggested by user areas and the effective knowledge sharing between the involved teams. This knowledge was essential to the continued operation and improvement of the system after its implementation.

\subsection{New resources and capabilities}

Our analysis indicated that new resources and capabilities continued to be developed even after the implementation of the ERP system was completed. They are described below. 
- Internalized change readiness: There was a paradigm shift in Dataprev when the implementation contractor shared with the company its expertise in business process management. Contrary to what had been observed in previous projects, employees' resistance was quite low. On the contrary, conscious of the benefits potentially obtained with an ERP that embeds the best practices of the industry, the participation of external consultants in the project was seen as an opportunity to improve work routines and exchange experiences and knowledge. This state of readiness to change remained in the post-implementation phase, as evidenced by the reaction to subsequent changes made in the company.

"...This whole process has also contributed to managers and teams expanding their own initiative capabilities, much less depending on the "boss ordering to do". (Respondent LOP).

Dataprev employees today are less resistant to changes and have come to consider change management important in their projects. (Respondent ITU)

- Analytic vision: The staff, enabled by new technological tools and greater availability of higher-quality information, began to spend more time on data analysis in their decision-making processes, which became more structured and consistent. The move towards a fact-based decision making was also favored by automation and faster execution of activities and business processes, as well as by better integration of the areas of the company.

"... Now we are moving to an interesting level to reach a next step (agile and analytical treatment of information) ..." (Respondent LOP).

- Standardized, efficient processes: With the standardization of processes made possible by the system, employees began to perform their activities in the same way, which resulted in greater predictability and transparency, better workload distribution, and higher productivity.

It was a project that went far beyond what we imagined. In addition to the ERP benefits, [we got] data integration, process rationalization... (Respondent LOP)

[Now,] most of the company already gets information practically in real time. (Respondent DAG)

- Document availability: The ERP system included a workflow module, which allowed for the storage, organization, and distribution of documents. After the go-live, users had faster and more reliable access to internal documents, which improved Dataprev's responsiveness to internal and external demands.

Today, the ERP allows you to view a copy of the contract, a copy of the terms of reference, and a copy of an invoice. So, I have access to information that makes me much more agile. This is a huge gain. (Respondent DAR) 
- Transparency: Given the changes in business processes promoted by the ERP project, responsibilities and workflow became clearer for all areas involved in organizational processes. A higher level of professionalism in the execution of activities was noticed, as process requirements and restrictions became more transparent and were followed by all parts involved.

[The project] implemented the conversation between the areas, and the conversation is working. There is still much to improve in this conversation, but the areas know each other today, and this is an improvent. (Respondent STT)

- Integration: In the post-implementation phase, integration and coordination among employees and Dataprev's areas in general increased substantially. The improvement favored a more intense, proactive, and agile exchange of information and, thereby, the achievement of company objectives.

\begin{abstract}
"If you are talking about integration, it was done..." and "The integration of the company and you have information more quickly". (Respondent ITI3).

"It was a project that went far beyond what we imagined. In addition to the ERP's own benefits: data integration" (Respondent LOP)

"The first thing is that you are able to gather the data in a consistent and unique database, that is indisputable, it is the biggest gain. Have consistency and speed in information, and the areas work in an integrated manner" (Respondent GST)
\end{abstract}

- Networking: Leveraged by the abovementioned resources and capabilities, there was a higher level of collaboration among employees and areas to solve the problems and address improvement opportunities. Staff seemed to enjoy greater autonomy, with less need for management intervention.

One thing I am happy to see is that the areas started to talk to each other more often. I think that's really cool. (Respondent STT).

"Today people talk more between areas. Before each one did their job and did not care about the other area..." (Respondent CJR)

- New processes for acquiring resources: With the ERP system and associated process redesign effort, Dataprev's procurement area was heavily modified. The new best practices, enabled by modern technological tools, helped the company increase its efficiency and effectiveness. Procurement processes and policies continued to be improved in the postimplementation phase.

"The middle area was seen as a major bottleneck for the company. It takes to hire, it takes to pay [...] Previously, the elaboration of projects was slow, processes were slow, the company's planning was slow, and this improved a lot". (Respondent LOP) 
- Management by indicators: The ERP system and the BI module allowed Dataprev to start using key performance indicators for planning and management purposes: "On this unique basis [ERP], you will be able to generate information for the indicators so that you can have guidance" (Respondent DAR). These practices helped the company meet compliance requirements, increase overall performance, and become more competitive.

- Internalized change management: The implementation project helped Dataprev develop considerable expertise in change management. Later, its IT area was able to not only apply it to other projects internally but also to offer it as a service to clients.

I think people got involved with the implementation and got so involved that the ERP implementation at Dataprev became a pilot, a successful case in such a way that change management stood out in this scenario. So everything says: I want change management for everything!" (Respondent ITI1).

\subsection{Complementarity}

The level of complementarity between IT resources and capabilities and other organizational resources and capabilities influences the impact of IT investments on organizational performance (Melville, Kraemer, \& Gurbaxani, 2004; Pappa, \& Stergioulas, 2008; Wade \& Hulland, 2004). Indeed, the resources above and capabilities would not provide by themselves the results that Dataprev expected to obtain. During the project and after its completion, a constant and prolific interaction between IT and organizational assets was observed. Resources and capabilities such as external relationships management, IT development, partnerships with the business areas, and planning and change management complemented and were complemented by change management, communication, and process management, and leveraged by change readiness, senior management commitment, and an appropriate organizational structure and cross-functional teams, composed of IT, business and external agents. For instance, if, on the one hand, technological solutions were assessed for their suitability to business needs, on the other hand, the latter were also adjusted to the technological limitations and the restrictions defined in the implementation project, vis-à-vis the broader organizational goals. Moreover, in the post-implementation phase, capabilities and resources continued to complement and reinforce each other, creating the necessary conditions for the continuous generation of business value, as organizational practices and IT assets were mutually aligned and adjusted.

The high degree of complementarity between IT and organizational resources and capabilities was evident in the constant interaction and reciprocal support between various elements of the organizational context. In particular, we highlight the availability of committed and properly trained human resources, who were allocated in organizational structures that were integrated through optimized processes, backed up by suitable and frequently revised technological assets, in an environment marked by intense knowledge sharing among internal agents and their external peers. 
As proposed by Nevo and Wade (2010), due to the high complementarity level of its IT and organizational resources and capabilities, Dataprev has been able to develop new resources and capabilities that allows it to continue to extract value from an IT investment made five years before. By the end of this study, the company had showed increased analytical capacity, supported by transparent, integrated, and efficient systems and processes, which were able to supply the organizational agents with relevant and timely information flows. Moreover, this new set of resources and capabilities, which also operated in an integrated manner, was highly adaptable and permeable to new ideas.

\subsection{Dynamic capabilities}

Given the significant number of reports of failures in large implementations of corporate systems, it is important to understand why Dataprev's ERP project was such a success. The reasons for this seem to be associated with the concept of dynamic capabilities, which reflects the company's ability to renew its critical competencies in response to changes in its business environment. Pavlou and Sawy (2011) suggest that the dynamic capabilities used by companies to reconfigure their operational capabilities are composed of four dimensions: sensing, learning, integrating, and coordinating. Organizations that have adequate dynamic capabilities can identify changes in the external environment, internalize relevant knowledge, generate and implement new solutions from this knowledge, and monitor and coordinate the integration of these solutions into its operations. The following describes how each of these dimensions was present in Dataprev's case.

- Sensing: Dataprev was able to accurately identify its deficiencies and detect market threats and opportunities related to the changing needs of its clients, stronger compliance requirements, and the availability of potential sources of technological resources and knowledge, such as the partners it later brought into the project. Also, during and after the project, it correctly detected problems and improvement opportunities related to gaps between internal processes, ERP functionalities, and skills of its workforce, and identified new potential partners and the opportunity to provide change management services.

- Learning: Through the establishment of fruitful relationships with its partners, Dataprev acquired knowledge about change, project, and process management, ERP systems implementation, and Business Intelligence. This knowledge allowed the company to detect (sense) new threats and opportunities, such as the risks arising from excessive customization of an ERP system and the demand for change management services. Internalization occurred through cross-functional team interactions, new organizational structures, business process redesign, workforce training, and greater transparency of operations and decision-making. Once internalized, this knowledge was recombined, transformed, and exploited, leading to the development of a higher analytical capacity and the adoption of governance structures that were adapted to its reality. 
- Integration: Dataprev has been able not only to contribute and develop specific knowledge within its IT and business areas but to incorporate them into integrated and transparent operating standards. Several of the company's components began to act in a more coordinated way, connected by clear and timely work and information flows. The knowledge absorbed by Dataprev's areas has turn into solutions that permeated the organization, using the project as a conducting wire, and later, the new ERP system. The use of cross-functional teams, the development of more robust intra- and extra-organizational social networks, and the creation of the advisory committee demonstrate the existence of knowledge and experiences contribution, representation, and interrelationship mechanisms (Pavlou \& El Sawy, 2011).

- Coordination: Dataprev has shown the ability to implement solutions and continuously adapt them depending on the problems and opportunities that arose during and after the project. For example, the expertise in change management developed during the project and its potential transformation into a new service to internal and external clients denotes Dataprev's ability to materialize new solutions composed of arrays of features and capabilities it had reconfigured.

Figure 7 graphically illustrates the development and reconfiguration process of resources and capabilities observed in Dataprev, which was enabled by its dynamic capabilities.

Figure 7 - Dynamic Capabilities in the ERP system Implementation Process

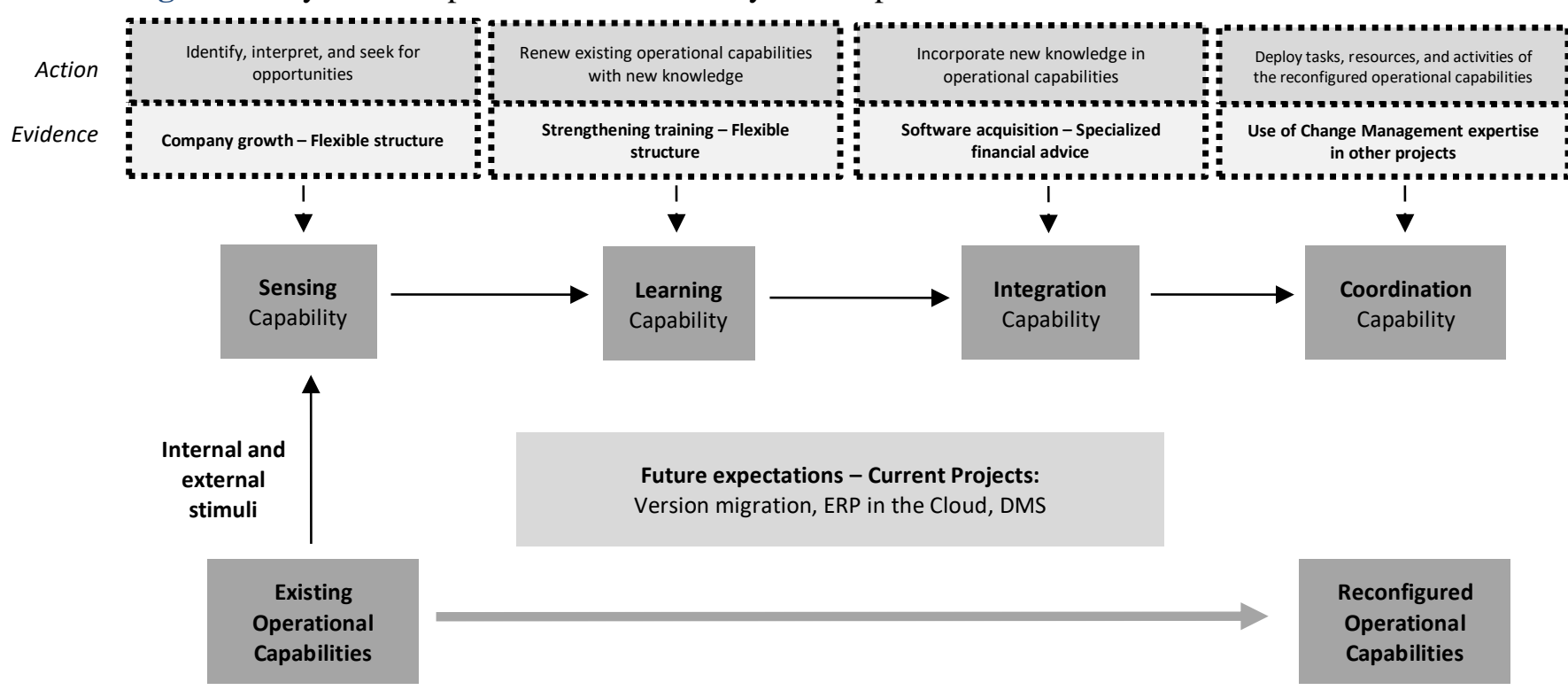

Source: Adapted from Kurtz et al. (2013, p.13)

The aforementioned dynamic capabilities acted not only throughout the ERP project but also before it began and after its completion. According to Nevo and Wade (2010), the complementarity of resources and capabilities is influenced by their compatibility and the organization's integration efforts. In Dataprev's case, the dynamic capabilities were essential to promote such integration and to increase the compatibility between IT and organizational resources and capabilities. Thus, without them, the 
company's chances to succeed in the ERP implementation and to continuously extract business value from its investment would be significantly reduced.

At the end of our study, Dataprev had several projects underway that evidenced its ability to identify, interpret, absorb, and implement new business solutions. The migration to a later cloud-based version of the ERP system and the implementation of a new document management system are examples of the opportunities the company has been able to identify recently. Dataprev was about to reconfigure its assets to absorb and/or develop the related competencies when we finished our research. Elicited mainly by the existence of the above mentioned dynamic capabilities, these new resources and capabilities will be built via the dynamics that occurred along with the ERP project.

Figure 8 consolidates the results of the analysis presented in the last sections.

Figure 8 - Dataprev's Resources and Capabilities Structure

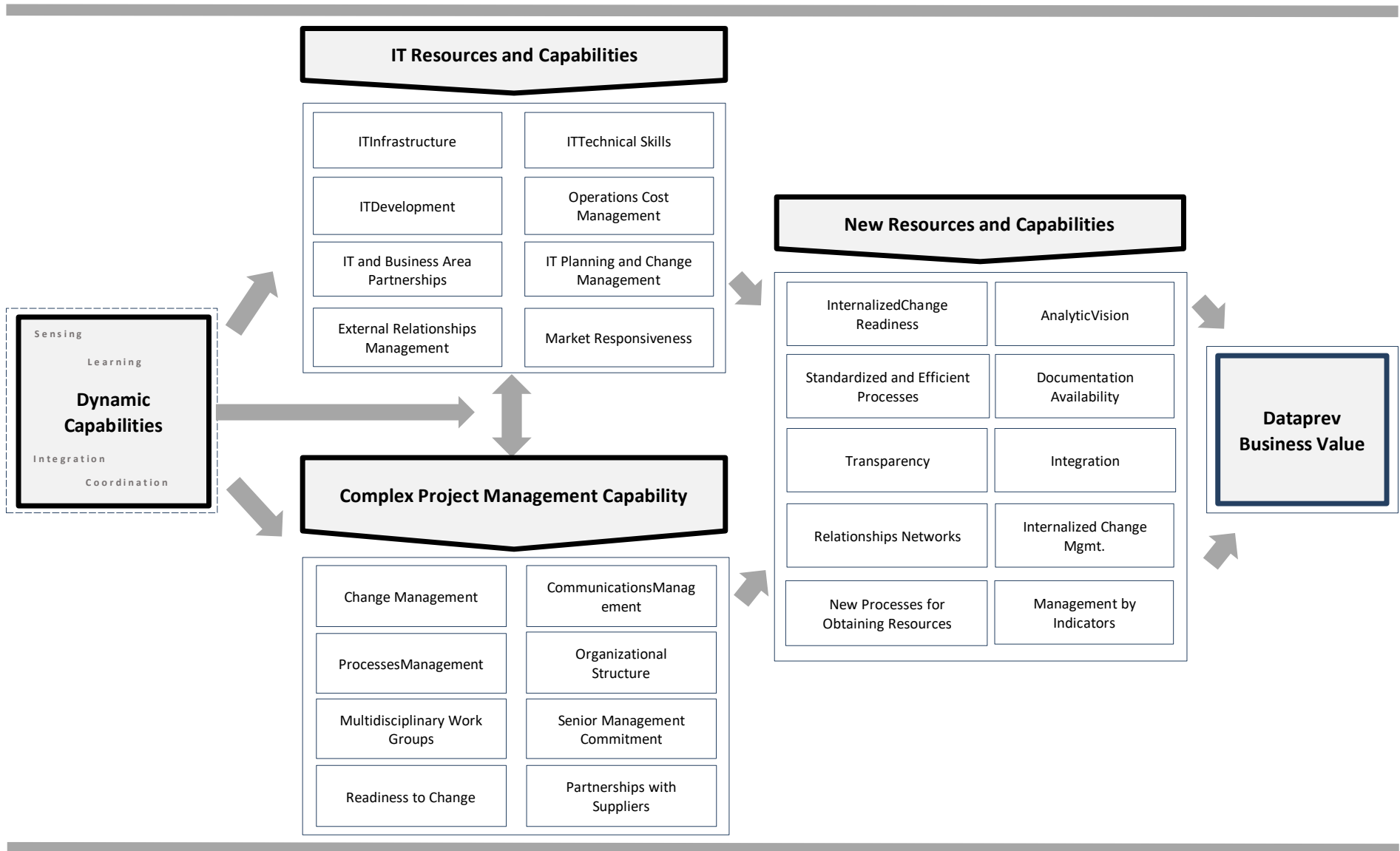

Source: The authors

\section{Conclusion}

This study described how IT and organizational resources and capabilities complement each other to generate business value. Furthermore, it highlighted the essential role of dynamic capabilities in the adoption of new information systems and in extracting value from the corresponding investment. Its contribution derives from the clarification of the dynamics that intertwines dynamic capabilities, 
complementarity, the development of resources and capabilities, and the generation of value from IT investments. The case study provided qualitative empirical evidence for these dynamics and numerous examples of resources and capabilities that were essential for the achievement of Dataprev's objectives.

More specifically, it was clear that the continuous generation of value from the implementation of the ERP system by the company depended on the prior existence of dynamic capabilities, which acted to increase the level of complementarity between the resources and capabilities involved in the project and the post-implementation phase. Dataprev's superior results depend not only on the acquisition and development of adequate IT resources and capabilities but also on the convergence of IT and organizational assets, which complemented each other and leveraged the adoption process. Without them, the company would hardly achieve such positive results, nor seize the opportunities made possible by the resources and capabilities developed over the implementation and use of the ERP system.

In harmony with RBV's premise that a firm's competitive advantage is grounded on the unique set of resources that it has access to and controls, Dataprev's increased performance and competitiveness seem to be a result of the synergistic development of new company-specific resources and capabilities. To the extent that they have been shaped by and are embedded in that sociohistorical context, these new assets are not only capable of generating value, but also rare and hard to imitate, replace, or transfer. Therefore, as suggested by Nevo and Wade (2010), they should be a potential source of sustained competitive advantage.

The limitations of our research include the reliance on interviewees' capacity to remember project-related events accurately a posteriori. Although we used project documentation and company memos and public releases to triangulate our findings and increase their reliability, we suggest that future studies adopt a longitudinal research strategy and follow the unfolding of IT investments as it takes place.

Additionally, in order to investigate the phenomena of interest in greater depth, we chose to focus on a single ERP implementation project and its subsequent events. However, companies operate in different sectors and macro environments, and, thereby, develop and are subject to several peculiarities, which may alter the dynamics we studied in our research. This possibility should not be discarded even for companies operating in the same sector, as they also tend to develop their idiosyncrasies. Thus, future qualitative studies should explore new business contexts and types of companies (e.g., public vs. private, large vs. small), as well as different types of IT investments. Finally, the research portrays the actions that occurred around 2014. Therefore, new research with the data can enrich the results found with the current actions.

\section{References}

ABES (2019). Brazilian Software Market: Scenario and Trends. Available at: http://central.abessoftware.com.br/Content/UploadedFiles/Arquivos/Dados\%202011/ABESEstudoMercadoBrasileirodeSoftware2019.pdf. 
Anderson, M. C., Banker, R. D., \& Ravindran, S. (2006). Value implications of investments in information technology. Management Science, 52(9), 1359-1376.

Arvidsson, V., Holmström, J., \& Lyytinen, K. (2014). Information systems use as strategy practice: A multi-dimensional view of strategic information system implementation and use. The Journal of Strategic Information Systems, 23(1), 45-61.

Augier, M., \& Teece, D. J. (2009). Dynamic Capabilities and the Role of Managers in Business Strategy and Economic Performance. Organization Science, 20, 410-421.

Barney, J. B. (1991). Firm resources and sustained competitive advantage. Journal of Management, 17(1), 99-120.

Barney, J. B. (2001). Resource-based theories of competitive advantage: A ten-year retrospective on the Resource-Based View. Journal of Management, 27(6), 643-650.

Chadwick, C., \& Dabu, A. (2009). Human Resources, Human Resource Management, and the Competitive Advantage of Firms: Toward a More Comprehensive Model of Causal Linkages. Organization Science, 20(1), 253-272.

Chang, H.-H., \& Chou, H.-W. (2011). Drivers and effects of enterprise resource planning postimplementation learning. Behaviour \& Information Technology, 30(2), 251-259.

Eisenhardt, K. M., \& Martin, J. A. (2000). Dynamic Capabilities: What Are They? Strategic Management Journal, 21(10/11), 1105-1121.

Friese, S. (2014). Qualitative Data Analysis with ATLAS.ti (2nd ed.). Thousand Oaks, CA: Sage Publications.

Huesch, M. D. (2013). Are there always synergies between productive resources and resource deploymentimplementation capabilities? Strategic Management Journal, 34(11), 1288-1313.

Karimi, J., Somers, T. M., \& Bhattacherjee, A. (2007). The Role of Information Systems Resources in ERP Capability Building and Business Process Outcomes. Journal of Management Information Systems, 24(2), 221-260.

Kohlbacher, F. (2006). The Use of Qualitative Content Analysis in Case Study Research. Forum Qualitative Sozialforschung / Forum: Qualitative Social Research, 7(1). Retrieved from http://www.qualitative-research.net/index.php/fqs/article/view/75/153.

Kouki, R., Poulin, D., \& Pellerin, R. (2010). The Impact of Contextual Factors on ERP Assimilation: Exploratory Findings from a Developed and a Developing Country. Journal of Global Information Technology Management, 13(1), 28-55.

Kurtz, D. J., Santos, J. L., \& Steil, A. V. (2013). Knowledge absorption capacity and Dynamic Capabilities in the Context Turbulent environments: a literature review. IV meeting of information management.

Mata, F. J., Fuerst, W. L., e Barney, J. B. (1995). Information technology and sustained competitive advantage: a resource-based analysis. MIS Quarterly, 19, 487-505.

Mayring, P. (2000). Qualitative Content Analysis. Forum Qualitative Sozialforschung / Forum: Qualitative Social Research, 1(2). Retrieved from http://www.qualitativeresearch.net/index.php/fqs/article/view/1089/2385. 
Melville, N., Kraemer, K., \& Gurbaxani, V. (2004). Review: Information Technology And Organizational Performance: An Integrative Model Of IT Business Value. MIS Quarterly, 28(2), 283-322.

Nevo, S., \& Wade, M. R. (2010). The Formation and Value of IT-enabled Resources: Antecedents and Consequences of Synergistic Relationships. MIS Quarterly, 34(1), 163-183.

Pappa, D., \& Stergioulas, L. K. (2008). The emerging role of corporate information systems: An example from the area of business process-oriented learning. Int. Journal of Business Science and Applied Management, 3(2). Available at: http://www.business-andmanagement.org/paper.php?id=29.

Pavlou, P. A., \& El Sawy, O. A. (2011). Understanding the Elusive Black Box of Dynamic Capabilities. Decision Sciences, 42(1), 239-273.

Penrose, E. (1959). The theory of the growth of the firm. Oxford: Basil Blackwell.

Portugal Vasconcelos Ferreira, M. A. S., Reis, N. R., Ribeiro Serra, F. A., \& Kramer Costa, B. (2014). Understanding the Footprint of the RBV in International Business Studies: the Last Twenty Years of Research. Brazilian Business Review, 11(4), 53-83.

Schryen, G. (2013). Revisiting IS business value research: what we already know, what we still need to know, and how we can get there. European Journal of Information Systems, 22, 139-169.

Selznick, P. (1957). Leadership and administration. (Harper \& Row, Ed.). New York.

Staehr, L. (2010). Understanding the role of managerial agency in achieving business benefits from ERP systems. Information Systems Journal, 20(3), 213-238.

Stanciu, V., \& Tinca, A. (2013). ERP solutions between success and failure. Accounting and Management Information Systems, 12(4), 626.

Teece, D. J. (2007). Explicating dynamic capabilities: the nature and microfoundations of (sustainable) enterprise performance. Strategic Management Journal, 28(13), 1319-1350.

Teece, D. J., Pisano, G., \& Shuen, A. (1997). Dynamic Capabilities and Strategic Management. Strategic Management Journal, 18(7), 509-533.

Wade, M., \& Hulland, J. (2004). The Resource-Based View and Information Systems Research: Review, Extension, And Suggestions For Future Research. MIS Quarterly, 28(1), 107-142.

Wernerfelt, B. (1984). A Resource-Based View of the firm. Strategic Management Journal, 5, 171-180.

Winter, S. G. (2003). Understanding Dynamic Capabilities. Strategic Management Journal, 24, $991-$ 995. 